\title{
Rating of the Activities of Urban Transport Policy in the Context of Sustainable Development
}

\author{
Victor Nordin \\ Kaliningrad State Technical University, Russian Federation \\ Nikolai Kharitoshkin \\ United Nations Development Program, Russian Federation \\ Agnieszka Czerwińska-Lubszczyk \\ University of Technology and Humanities in Bielsko-Biała, Poland
}

2020

Volume 3

Issue 1

pp. 355-366

Date of submission to the Editor: 02/2020

Date of acceptance by the Editor: 03/2020

\section{INTRODUCTION}

Greenhouse gas emissions are a serious concern with recent climatic changes, witch impacts on human and natural systems. Intergovernmental Panel on Climate Change (con-nected with United Nations) noticed - limiting global warming require drastic reductions of global emissions (Karlsson, Rootzen \& Johnsson, 2020). The European Union has been promoting social innovation and new business models to support the long-term transition towards low-emission, sustainable urban development (Angelidou et all, 2020). The 2030 Agenda for Sustainable Development which was adopted by United Nations member states is a plan and direction for future prosperity (Milca \& Milca, 2019). Nowadays sustainable development is connected with every aspect of human life. The Societal grand challenge requires joint efforts by private, public, and social sector organizations (Günzel-Jensen et all, 2020). In many cities of the world due to the growing motorization, despite the largescale street-road construction, starting from 1970s the transport problems have drastically worsened leading to the environmental degradation. Reaserchers notice the city problems. For example Karlsson, Rootzen \& Johnsson (2020) assesses the potential for reducing the climate impact of road construction. Burghardt \& Pashkevich (2020) focused on materials selection for road markings. Davis-Sramek and all (2020) focused on trucking companies. Angelidou et all (2020) presented results from the Horizon 2020 Research and Innovation Project "Cities-4-People", financed under the 'Smart, green and integrated transport'. The results showed that citizens and stakeholders have a deeper knowledge of their own area's particular needs. Sovacool \& Griffiths (2020) focused on how culture can complicate and impede attempts at promoting more efficient, more sustainable, and often more affordable forms of mobility. They illustrated the cultural barriers to a low-carbon, low-energy future. Andersson (2020) explored the preconditions affecting the motivation 
of people to reduce private car use. Sjöman et all' (2020) findings support the view that privately owned cars are hard to replace with new mobility services (that contribute to sustainability). Sjöman et all (2020) explored everyday mobility by use of interventions in people's everyday lives. They focused on identifying underlying factors that may motivate or hinder changes that are positive from a sustainability perspective. Results can be used for impoved perspective of new mobility services and policy making.

There is a growing awareness that instead of increasing capacity of the city roads, it is necessary to implement effective management of the urban transport system through introduction of new approaches to their planning.

The aim of this chapter is describe the conditions and measures to reduce the negative impact of problems combined into transport policy measures in two ways: increasing use of public transport and limiting use of private cars. The method of expert assessments allowed to rank these activities in order to establish the sequence of their implementation in cities in order to bring their state closer to the "livable city".

\section{URBAN TRANSPORT SYSTEM PLANNING AND SUSTAINABLE DEVELOPMENT}

At the present time the freedom of mobility has become the major factor of social integration along with accommodation, health and education. It is necessary to provide the mobility of citizens regardless of their age, sex, income, degree of integration, physical abilities or place of residence. So, it is very important to strive for the development of universal, accessible, inclusive transport system based on the principles of equality and excluding any type of discrimination.

Mobility of citizens and goods is, on the one hand, a key factor in the development of a city, but, on the other hand, - it is the result of that development. In the last few decades people witnessed great social, demographic, cultural and economic changes which have a significant impact on transport mobility. Such factors as the growth of urban population, income growth, development of a consumer market, as well as new directions in the urban development have resulted in a considerable increase in the number of motor vehicles. As the consequence of this process originally intended to meet the emerging needs, new tasks requiring solutions have appeared.

It is necessary to focus on the improvement of mobility system to make a city more "livable", attractive and comfortable for everybody; to be accessible and meet the basic mobility needs of all the users; to balance various needs of transport services to provide services to the public, business and industrial facilities; to respond accordingly to the demands for transport services to the citizens, business, industrial facilities; to rely on the principles of balanced development and maximum integration of different transport modes; to meet the requirements of sustainability, balance the needs of economic benefit, social equality, public health services and protection of the environment; to increase the effectiveness and profitability; to make better use of urban space, infrastructure and available transport services; to improve the appearance of the 
cities, quality of life and health services; increase safety on the roads and streets; to decrease atmospheric and noise pollution, gas emissions resulting in greenhouse effect, energy consumption; to contribute to increasing overall effectiveness of the international transport system as a whole.

Thus, on the basis of the definitions of the sustainable transport (Litman, 2009) and sustainable transport systems, it is necessary to put forward the definition which is more relevant, covering different aspects of the problem related to functioning of urban transport systems (Chester \& Horvath, 2008) as follows:

Sustainable urban transport system - is a certain state of transport system, which enables to provide socially and economically justified volume of traffic, does not cause harm to humans and environment, and does not violate human rights of currently living and future generations.

Sustainable urban transport system covers three areas: environment., economics and society.

\section{Environment}

Reducing the impact on the natural environment is a strategy of insuring sustainability of our cities. Transport makes its contribution to harmful emissions into atmosphere, noise and climate change. About $15 \%$ of all greenhouse gases and $22 \%$ of $\mathrm{CO}_{2}$ emissions come from transport. Modern transport systems try to raise the level of environmental quality, but at the same time the global vehicle population is also increasing. Improving impact of the transport system on land use, and especially impact of construction and maintenance of infrastructure these are strategic goals set out to be achieved. Transport systems are waste generators (utilization of transport equipment, spare parts, packaging, etc.), the number of which should be reduced, re-used or recycled.

\section{Economics}

Transport is the factor of economic growth, development and employment. It needs highly effective resources: materials, infrastructure and energy. With fair strategy of price formation the consumers should pay all the expenses (direct and indirect costs), related to the use of transport system. Transport system with fair and open competition will most likely facilitate the choice and growth of the transport efficiency.

\section{Society}

Sustainable transport should benefit the society. Transport should be safe, doing no harm to human health and minimizing its negative impact on people. Access and fairness are two important principles because transport should promote access to goods and services for the largest possible number of people.

The concept of sustainability supports the change of the paradigm, taking place in transport planning nowadays. In the past, transportation was estimated, first of all, with regard to its mobibility (physical movement), but nowadays it is more 
and more often estimated with regard to its accessibility (ability of people to have access to desired goods and services). Accessibility is subjected to many factors, among them mobility, land-use considerations (such as location of activities) and substitutes of mobility (such as communication services and delivery services).

All this to the full extent apply to transport services in cities, which are subjected to the negative impact connected with "cities and car clash", because of total motorization. These problems are related to a low level of people's awareness of the transport system efficiency. The main ones include the following:

- Traffic jam, resulting in aggravating the harmful effect of transport means on the environment, as well as negative health impacts on the citizens, decline in the safety of traffic and throughput capacity of the street-road network (as a result, speed reduction of the public passenger transport), increase in fuel consumption, etc.

- Deficit of parking lots most visible as "occupation" of domestic territories and driveways by all kinds of transport means, which cause inconveniences to the residents, especially to those living on the lower floors. Cars emit noise and exhaust gases, interfere with the movement of pedestrians and cyclists, reduce the territory of lawns and greeneries.

- Cities become uncomfortable to live in, because of the increase of parking lots and mainstreaming of the street-road network, resulting in degradation of the urban and historical landscape.

- Decreasing mobility of citizens and potential of emergency services to perform their functions because of the increase in travel time and inability of timely arrival to the destination.

To create conditions for "the city comfortable to live in" it is necessary to implement a transport policy in accordance with two parallel well-coordinated directions (Vuchik Vukan, 2011):

- Measures aimed at increasing use of public transport.

- Measures aimed at limiting use of private cars.

These measure are aimed at encouraging drivers to travel at least some of the trips by public transport. But, to put it into practice, travelling by public transport should meet high requirements of the passengers.

\section{STEPS AND MEASURES OF TRANSPORT PLANNING TO INCREASE ITS EFFICIENCY}

The following steps can help in solving the issues of urban transport (Cohen, 2006; Green Paper: Towards..., 2007; Marsden \& Stead, 2011; Newman \& Kenworthy, 1999):

- Creating additional road capacity by building detours for redirecting throughtraffic rather than by introducing additional road capacity in form of new or improved highways that require bigger areas and inevitable demolition of residential and commercial real estate. 
- Incorporation of the traffic organization schemes associated with changes in transport streams and directions without any serious structural changes of an existing streets structure. Among the most commonly used measures extension of one-way traffic systems, changes of traffic light modes for increasing the capacity of road network, parking limitations and loading of vehicles on main roads. The tools used for this are intellectual transport systems including those connected to cars' on-board computers.

- Priority use of public transport (first of all, light-rail transport and buses). This involves allocation and/or designation of public transport routes on the road network and application of the Park-and-Ride system ("park and ride in public transport").

- Parking limitations have the following advantages: they are easy in administration, flexible in application, and easily understood by the public. Its weakness is the forced implementation because the drivers tend to park at an unauthorized place and evade fines. Besides, the fines for parking are often lower that the cost of one parking spot.

- Development of cycling the advantages of which have long been recognized. This flexible form of transportation is noiseless, environmentally friendly, energy-efficient, compact, and not threatening to the majority of other areas of road traffic; it also contributes to a healthy lifestyle.

- Encouragement of walking. Walking is the most important type of mobility often neglected by many project organizations, which develop traffic management. As a result of this neglect, facilities specifically designed for walking are often either absent or badly maintained. Meanwhile, pedestrians comprise the biggest category of deaths among the users of road traffic. There are social, medical, ecological and economic reasons for promoting walking as it is a fair, healthy, environmentally friendly, and inexpensive form of mobility. Moreover, "pedestrian towns" are generally pleasant places for living with access to facilities within walking distance, which is a key indicator of the quality of life.

- Promotion of public transport. Cycling and walking are suitable for short distances, however, in order to provide effective functionality of the city a high-quality public transport network is needed for longer distances.

This means:

- Rates should be reasonable so that the city dwellers could afford it.

- The transportation offer should satisfy the transport demand with high quality of service.

- Road network should satisfy the transport demand.

- A higher speed of public transportation should be ensured via separate lanes and minimization of time in automobile "traffic jams".

- It is necessary to coordinate the routes of public transportation in presence of multimodal tickets for passengers.

Efficiently planned transport network in cities and regions allows ensuring the implementation of socially and economically justified volume of transport without 
damaging human health and the environment, and also without violating rights of present and future generations.

In many countries, in cities' transport planning aimed at creating stable social, ecological, and economic basis for increasing the quality of life, the term "sustainable mobility" has long been entrenched. It precisely reflects the main goal of planning the efficient transport system in cities and regions.

"Unfortunately," states Prof. V. Vuchik, a famous expert in transport planning and transport systems development, "technological innovations still attract much more attention and receive much more generous funding than more fundamental (and much more complicated) problems associated with the citytransport relationship on a systemic level" (Vuchik Vukan, 2011).

The following are the four levels of transport planning described by Vuchik in his book (Vuchik Vukan, 2011):

- Individual facilities of transport infrastructure.

- Traffic network and system of one-mode transportation.

- Integrated, intermodal, coordinated transport system of the city as a whole.

- Interconnection at the balance level of the city and transport system.

Quite promising is the concept of transport and urban development called "Livable Cities" (Vuchik Vukan, 2011).

Another modern concept is standard TOP (transit-oriented development), which implies a high-quality thought-through planning and design of various types of land use, building and structures in order to support, popularize, and prioritize not only usage of public transport, but fundamental types of mobility such as walking and cycling (Standart TOR versiya).

An effective planning sequence of sustainable urban transport systems is shown in the Figure 1 below.

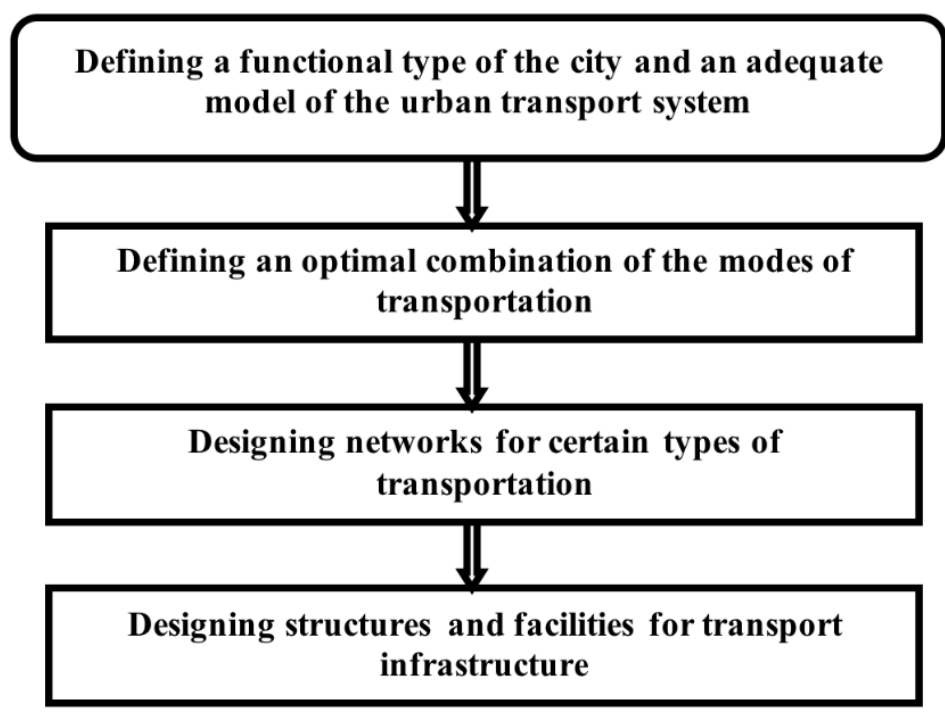

Fig. 1 Stages of city transport system planning

In "Livable Cities" measures of transport policy should be implemented in two parallel coordinated directions (Vuchik Vukan, 2011; Nordin, 2016) 


\section{Measures facilitating the use of public transport:}

1.1. The right of way of UPT (urban public transport) (designated and isolated lanes, ATCS) in the street-road network of the city.

1.2. Renovation of the public transport car park with higher comfort.

1.3. Incorporation of a universal transit pass for all types of UPT with varied ticket menu.

1.4. Creating comfortable conditions for pedestrians and cyclists.

1.5. Creating information system about UPT operation for passengers.

1.6. Realization of urban planning policies, taking into account the satisfaction of transport demand.

1.7. Realization of an awareness raising campaign aimed at changing transport behavior.

\section{Measures restricting the use of cars:}

2.1. Car transit limitations in certain zones and at a specific time.

2.2. Introducing tolls for roads or entrance to certain zones.

2.3. Ban or restrictions on parking time in certain zones.

2.4. Creating paid parking spaces in the city center.

2.5. Requiring that car owners have a residential parking for their cars.

2.6. Limiting the maximum allowed number of parking spaces.

2.7. Limiting the construction of multiband highways in urban areas.

2.8. Introducing constructive traffic pacifying measures in urban areas.

\section{EXPERT RANKING OF TRANSPORT POLICY MEASURES}

To evaluate the priority of the aforementioned measures the method of expert assessment (Nordin, 2010) has been selected. A number of specialists in the field of transport planning from different regions of Russia have been invited to participate in this work.

At first, the weight of 4 criteria was evaluated. Then the measures of transport policies were compared in accordance with these criteria. These are the following criteria:

- Effects of the measures on the citizens' quality of life.

- Lower financial cost.

- Acceptance by the majority of the city dwellers of the implementation of the measure.

- $\quad$ Time needed to implement the measure.

Expert assessment of the criteria converted into ranks and also their calculated standardized weights are shown in Table 1.

Evaluation of the concordance of opinions is carried out via calculation of the concordance coefficient and Pearson's chi-squared test $X^{2}$. Intermediate calculated values are shown in Table 2.

The sum of the squares of the algebraic difference equals $\mathrm{K}=187.5$. Theoretically possible maximum sum of the squares of the algebraic difference is calculated: 
where:

$$
K_{\max }=1 / 12 m^{2}\left(n^{3}-n\right)
$$

$\mathrm{m}$ - a number of experts (we have 8);

$\mathrm{n}$ - a number of objects being compared (we have 4).

$$
\mathrm{K}_{\max }=1 / 12 * 8^{2}\left(4^{3}-4\right)=320
$$

Concordance coefficient

$$
\mathrm{K}_{\text {conc }}=\mathrm{K} / \mathrm{K}_{\max }=0.59
$$

\begin{tabular}{|c|c|c|c|c|c|c|}
\hline \multirow{2}{*}{\multicolumn{2}{|c|}{$\begin{array}{l}\text { Experts/ } \\
\text { criteria }\end{array}$}} & \multicolumn{4}{|c|}{ Criteria } & \multirow[t]{2}{*}{$\begin{array}{l}\text { Total } \\
\text { score }\end{array}$} \\
\hline & & \multirow{2}{*}{$\begin{array}{c}\begin{array}{c}\text { Effects of the } \\
\text { measures on the } \\
\text { citizens' quality } \\
\text { of life }\end{array} \\
4\end{array}$} & \multirow{2}{*}{$\begin{array}{c}\text { Lower } \\
\text { financial cost } \\
2\end{array}$} & \multirow{2}{*}{$\begin{array}{c}\text { Acceptance by the } \\
\text { majority of the city } \\
\text { dwellers of the } \\
\text { implementation of } \\
\text { the measure } \\
3\end{array}$} & \multirow{2}{*}{\begin{tabular}{|c}
$\begin{array}{c}\text { Time needed to } \\
\text { implement the } \\
\text { measure }\end{array}$ \\
1
\end{tabular}} & \\
\hline \multirow{9}{*}{ 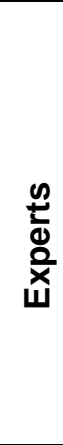 } & 1 & & & & & 10 \\
\hline & 2 & 3 & 3 & 1 & 3 & 10 \\
\hline & 3 & 4 & 2.5 & 1 & 2.5 & 10 \\
\hline & 4 & 4 & 1.5 & 3 & 1.5 & 10 \\
\hline & 5 & 4 & 2.5 & 1 & 2,5 & 10 \\
\hline & 6 & 4 & 3 & 1.5 & 1.5 & 10 \\
\hline & 7 & 4 & 3 & 2 & 1 & 10 \\
\hline & 8 & 4 & 3 & 2 & 1 & 10 \\
\hline & $\begin{array}{c}\sum \text { of } \\
\text { ranks } \\
S_{j}\end{array}$ & 31 & 20.5 & 14.5 & 14 & 80 \\
\hline \multicolumn{2}{|c|}{ Weight } & 0.39 & 0.26 & 0.18 & 0.17 & 1 \\
\hline
\end{tabular}

Table 1 Expert assessment of the weight of the criteria

Table 2 Intermediate results of concordance evaluation

\begin{tabular}{|l|c|c|c|c|}
\hline \multirow{2}{*}{$\begin{array}{c}\text { The order of } \\
\text { determining } \\
\text { calculated values } \\
\text { for concordance } \\
\text { coefficient }\end{array}$} & $\begin{array}{c}\text { Effects of the } \\
\text { measures on } \\
\text { the citizens' } \\
\text { quality of life }\end{array}$ & $\begin{array}{c}\text { Lower } \\
\text { financial } \\
\text { cost }\end{array}$ & $\begin{array}{c}\text { Acceptance by the } \\
\text { majority of the city } \\
\text { dwellers of the } \\
\text { implementation } \\
\text { of the measure }\end{array}$ & $\begin{array}{c}\text { Time needed } \\
\text { to implement } \\
\text { the measure }\end{array}$ \\
\hline 1. Sum of ranks $\boldsymbol{S}_{\boldsymbol{j}}$ & 31 & 20.5 & \multicolumn{3}{|c|}{14.5} & 14 \\
\hline 2. Average value $\overline{\boldsymbol{S}}$ & \multicolumn{5}{|c|}{20} & -6 \\
\hline $\begin{array}{l}\text { 3. Algebraic } \\
\text { difference, } \\
\boldsymbol{S}_{\boldsymbol{j}}-\overline{\boldsymbol{S}}\end{array}$ & 11 & 0.5 & -5.5 & 36 \\
\hline $\begin{array}{l}\text { 4. Squares of an } \\
\text { algebraic difference }\end{array}$ & 121 & 0.25 & 30.25 & 36 \\
\hline
\end{tabular}

Calculated value of Pearson's criterion

$$
X^{2} P=\mathrm{K}_{\text {conc }} \cdot \mathrm{m}(\mathrm{n}-1)=0,59^{\star} 8(4-1)=14,16 .
$$

The Table values of Pearson's criterion $\boldsymbol{X}^{2} \boldsymbol{T}$ depend on accepted weight level and a number of degrees of freedom is calculated using the formula $v=n-1$. $X^{2} T=7.81$ (when $\alpha=0.05$ and the number of degrees of freedom is equal to 3 ). (Sigiel 2002, Table 17.2.1).

Because $X^{2} P>X^{2} T$, the expert opinions are considered concordant with the probability of 0.95 . 
Next, the paired comparisons method (Günzel-Jensen et al. 2020) was applied for sequential comparison of measures of transport policies in each of the two directions based on 4 criteria. To do this, the experts were given the tables (matrix of priority) in Excel and were requested to input signs of priority. An example of the table completed by one of the matrix experts is shown in Table 3.

Table 3 Expert ranking of measures of transport policies of the first group based on the criterion "Effects of the measures on the citizens' quality of life"

\begin{tabular}{|c|c|c|c|c|c|c|c|c|c|}
\hline & \multicolumn{7}{|c|}{ Measures } & \multirow{2}{*}{$\boldsymbol{\Sigma}$} \\
\hline & & 1.1 & 1.2 & 1.3 & 1.4 & 1.5 & 1.6 & 1.7 & \\
\hline \multirow{7}{*}{ 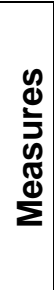 } & 1.1. & $=$ & + & - & $=$ & + & $=$ & + & 8 \\
\hline & 1.2. & - & $=$ & $=$ & $=$ & + & $=$ & + & 7.5 \\
\hline & 1.3. & + & $=$ & $=$ & - & + & - & $=$ & 7 \\
\hline & 1.4. & $=$ & $=$ & + & $=$ & + & $=$ & + & 8.5 \\
\hline & 1.5. & - & - & - & - & $=$ & - & $=$ & 4.5 \\
\hline & 1.6. & $=$ & $=$ & + & $=$ & + & $=$ & + & 8.5 \\
\hline & 1.7. & - & - & $=$ & - & $=$ & - & $=$ & 5 \\
\hline
\end{tabular}

The last column presents the line-by-line sums of points with the replacement of priority signs by the numeric values: «-»- 0.5; «=»-1.0; «+»-1.5.

All the matrixes of both groups based on all the criteria were built analogically. Tables 4 and 5 present processed total scores of the measures based on the criteria, with all the weights assigned to them by the experts in the worksheets taken into account.

Table 4 Final scores of expert assessment of the measures facilitating the use of public transport

\begin{tabular}{|c|l|l|l|l|l|c|}
\hline \multirow{2}{*}{ Measures } & \multicolumn{5}{|c|}{ Criteria } & \multirow{2}{*}{ Ranks } \\
\cline { 2 - 6 } & $\mathbf{1}$ & $\mathbf{2}$ & $\mathbf{3}$ & $\mathbf{4}$ & & \\
\hline 1.1. & 3.3 & 1.6 & 1.1 & 1.2 & 7.1 & 3 \\
\hline 1.2. & 2.7 & 1.4 & 1.2 & 1.1 & 6.3 & 6 \\
\hline 1.3. & 2.7 & 2.0 & 1.5 & 1.5 & 7.6 & 2 \\
\hline 1.4. & 3.5 & 1.8 & 1.9 & 1.4 & 8.6 & 1 \\
\hline 1.5. & 2.1 & 2.1 & 1.1 & 1.3 & 6.7 & 5 \\
\hline 1.6. & 3.1 & 1.8 & 1.1 & 0.9 & 6.9 & 4 \\
\hline 1.7. & 2.1 & 1.9 & 0.9 & 1.1 & 6.1 & 7 \\
\hline
\end{tabular}

Table 5 Final scores of expert assessment of the measures restricting the use of cars

\begin{tabular}{|c|c|c|c|c|c|c|}
\hline \multirow{2}{*}{ Measures } & \multicolumn{4}{|c|}{ Criteria } & \multirow{2}{*}{$\boldsymbol{\Sigma}$} & \multirow{2}{*}{ Ranks } \\
\hline & 1 & 2 & 3 & 4 & & \\
\hline 2.1 . & 3.6 & 2.3 & 1.4 & 1.5 & 8.7 & 2 \\
\hline 2.2 . & 3.5 & 1.9 & 1.1 & 1.2 & 7.7 & 6 \\
\hline 2.3. & 2.8 & 2.1 & 1,5 & 1.3 & 7.7 & 5 \\
\hline 2.4 . & 3.2 & 2.2 & 1.2 & 1.3 & 7.9 & 4 \\
\hline 2.5 . & 2.6 & 1.9 & 1.4 & 1.4 & 7.3 & 7 \\
\hline 2.6. & 2.9 & 2.3 & 1.7 & 1.5 & 8.4 & 3 \\
\hline 2.7 . & 3.5 & 2.7 & 1.9 & 1.8 & 9.9 & 1 \\
\hline 2.8. & 2.9 & 1.7 & 1.5 & 1.0 & 7.2 & 8 \\
\hline
\end{tabular}


Figure 2 and 3 shows a graphical interpretation of the results of expert ranking of measures that promote the use of public transport and measures that restrict the use of cars.

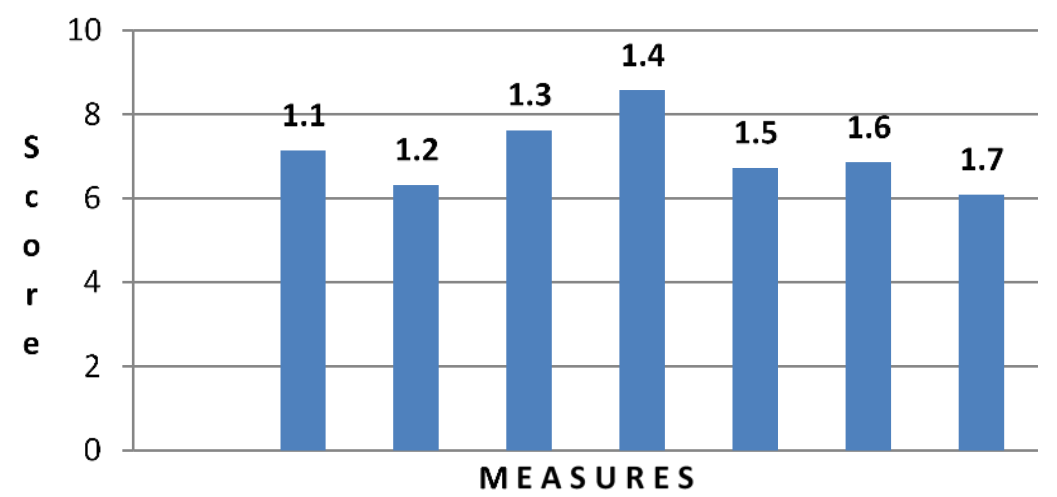

Fig. 2 results of expert ranking of measures: promoting the use of public transport

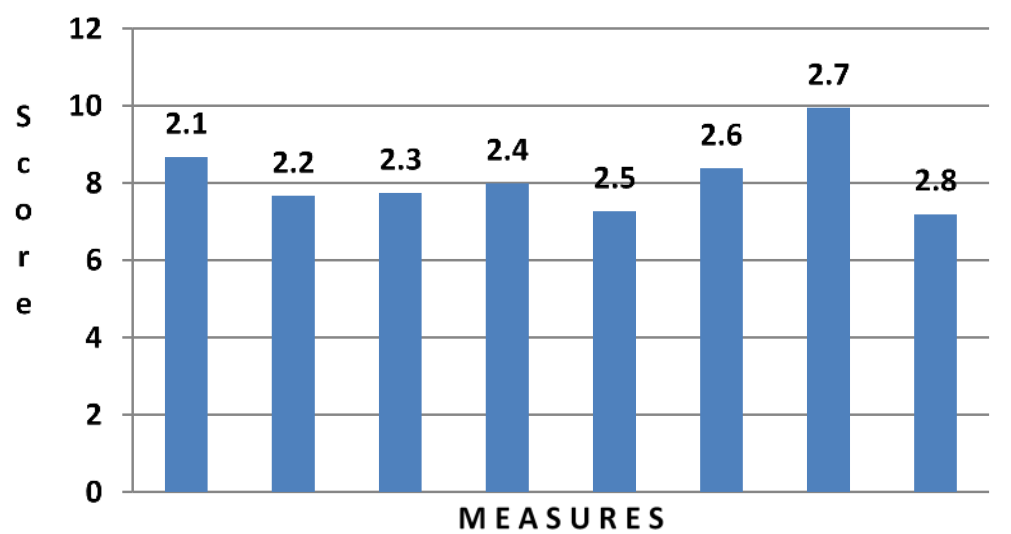

Fig. 3 results of expert ranking of measures: restraining the use of cars

\section{CONCLUSION}

The Sustainable Development Goals are the blueprint to achieve a better and more sustainable future for all. They address the global challenges we face, including those related to transport systems while simultaneously preserving natural resources our society and economics depend on.

There is no universal reasonable solution for all the urban transport systems. Architects, constructors, engineers, economists and technicians of transport have different opinions, but the solution to the problems of urban transport planning has to consider the time and cost of projects implementation.

The results of the study made it possible to establish the priority order of the measures of urban transport policies:

- Creating comfortable conditions for pedestrians and cyclists.

- Limiting the construction of multiband highways in urban areas.

- Incorporation of a universal transit pass for all types of UPT with varied ticket menu;

- Creating isolated lanes for UPT.

- Car transit limitations in certain zones and at a specific time.

- Limiting the maximum allowed number of parking spaces. 
It is advisable to implement these measures simultaneously in defined directions. The use of the obtained data as a "roadmap" for determining the sequence (order) of their implementation in the cities will bring their state closer to "livable cities". Moreover, the above-mentioned measures contribute to the achievement of the Sustainable Development Goals and help the urban transport systems become really "sustainable".

\section{REFERENCES}

Andersson, A. (2020) 'Is climate morality the answer? Preconditions affecting the motivation to decrease private car use', Transportation Research Part D, 102198, pp. 1-14.

Angelidou, M., Karachaliou, E., Matonaki, A. and Karaberi, C. (2020) 'Co-creating sustainable urban planning and mobility interventions in the city of Trikal', Earth and Environmental Science, 410, pp. 1-11.

Burghardt, T.E. and Pashkevich, A. (2020) 'Materials selection for structured horizontal road markings: financial and environmental case studies', European Transport Research Revie, 12(11), pp.1-10.

Vuchik Vukan, R. (2011) Transport v gorodakh, udobnykh dlya zhizni (Transportation for Livable Cities). M.: Territoriya budushchego. Available at: http://fanread.ru/book/ 8620468/ ?page $=1$.

Chester, M. and Horvath, A. (2008) Environmental Life-cycle Assessment of Passenger Transportation: A Detailed Methodology for Energy, Greenhouse Gas and Criteria Pollutant Inventories of Automobiles, Buses, Light Rail, Heavy Rail and Air, UC

Berkeley Center for Future Urban Transport. Available at: http://repositories.collib.org/its/future_urban_transport/vwp-2008-2.

Sigel, E. (2002) Prakticheskaya biznes-statistika.: Per. s angl. - M.: Vil'yams.

Standart TOR versiya 2.1/ Institut politiki transporta i razvitiya. N'yu-York/ Odobren Programmoy OON po naselonnym punktam. Available at: http://noc.h1n.ru/file/standart_TOR.pdf.

Cohen, B. (2006) 'Urbanization in Developing Countries: Current Trends, Future Projections, and Key Challenges for Sustainability', Technol. Soc. Available at: https://www.sciencedirect.com/science/article/pii/S0160791X05000588.

Davis-Sramek, B., Robinson, J.L., Darby, J.L. and Thomas, R.W. (2020) 'Exploring the differential roles of environmental and social sustainability in carrier selection decisions', International Journal of Production Economics, 227, pp. 1-9.

Green Paper: Towards a New Culture for Urban Mobility (2007) European Commission. Available at: http://eur-lex.europa.eu/legal-content/ EN/TXT/PDF/? uri=CELEX: 52007DC0551\&from $=$ EN.

Günzel-Jensen, F., Siebold, N., Kroeger, A. and Korsgaard, S. (2020) 'Do the United Nations' Sustainable Development Goals matter for social entrepreneurial ventures? A bottom-up perspective', Journal of Business Venturing Insights, 13, pp. 1-8.

Nordin, V.V. (2010) Prakticheskiye metody povysheniya kachestva upravleniya v transportnoy i servisnoy otraslyakh. Kaliningrad: Izd-vo BFU im. I. Kanta.

IPCC (2018) Summary for Policymakers. In: Global Warming of $1.5^{\circ} \mathrm{C}$. An IPCC Special Report on the impacts of global warming of $1.5^{\circ} \mathrm{C}$ above pre-industrial levels and related global greenhouse gas emission pathways, in the context of strengthening the global response to the threat of climate change, sustainable development, and efforts to eradicate poverty. Available at: https://www.ipcc.ch/site/assets/uploads/sites/2/2019/05/SR15_SPM_version_re port_LR.pdf (Accessed: 14.03.2020).

Karlsson, I., Rootzen, J. and Johnsson F. (2020) 'Reaching net-zero carbon emissions in construction supply chains - Analysis of a Swedish road construction project', Renewable and Sustainable Energy Reviews, 120, pp. 1-14. 
Litman, T. (2009) Sustainable Transportation Indicators. A Recommended Research Program for Developing Sustainable Transportation Indicators and Data, Transportation Research Board Annual Meeting, USA. Available at: https://codot.gov/projects/ contextsensitivesolutions/docs/pdfs/sti.pdf.

Marsden, G. and Stead, D. (2011) 'Policy Transfer and Learning in the Field of Transport: A Review of Concepts and Evidence', Transp. Policy, 18, pp. 492-500. Available

at: https://www.sciencedirect.com/science/article/pii/S0160791X05000588.

Milca, D. and Milca, J. (2019) 'Productive Employment and Working Conditions as Determinants of Sustainable Economic Development in Serbia', Studies in Business and Economics, 14(3), pp. 84-96.

Newman, P. and Kenworthy, J. (1999) Sustainability and Cities: Overcoming Automobile Dependence. Washington, DC, USA, Island Press. Available at: https://books.google.ru/books?hl=ru\&lr=\&id=pjatbiavDZYC\&oi=fnd\&pg=PR13\&o ts=BbJSuHsAyF\&sig=HUCFK6z5L6XjXUUw2E1ayukbm74\&redir_esc=y\#v=one page \&q\&f=false.

Nordin, V. (2016) 'Urban traffic problems of Kaliningrad and their solution', Systemy Wspomagania w Inżynierii Produkcji, 3, pp. 97-105.

Sjöman, M., Ringenson, T. and Kramers, A. (2020) 'Exploring everyday mobility in a living lab based on economic interventions', European Transport Research Revie, 12(5), pp. 1-17.

Sovacool, B.K. and Griffiths, S. (2020), 'The cultural barriers to a low-carbon future: A review of six mobility and energy transitions across 28 countries', Renewable and Sustainable Energy Reviews, 119, pp. 1-12.

\begin{abstract}
.
The growing number of cars cities is worsening the quality of life of our citizens, aggravating their problems with mobility, social inequality, health and ecology. The implementation of the Sustainable Development Goals implies carrying out measures aimed at reducing the impact of urban transport systems in three interrelated directions. The aim of this chapter is describe the conditions and measures to reduce the negative impact of these problems combined into transport policy measures in two ways. The method of expert assessments allowed to rank these activities in order to establish the sequence of their implementation in cities in order to bring their state closer to the "livable city".
\end{abstract}

Keywords: Environment, ecology, sustainable development, transport policy 